1905

\title{
Studies in Modern German Literature
}

Otto Heller

Follow this and additional works at: https://scholarsarchive.byu.edu/sophnf_essay

\section{BYU ScholarsArchive Citation}

Heller, Otto, "Studies in Modern German Literature" (1905). Essays. 1818.

https://scholarsarchive.byu.edu/sophnf_essay/1818

This Article is brought to you for free and open access by the Nonfiction at BYU ScholarsArchive. It has been accepted for inclusion in Essays by an authorized administrator of BYU ScholarsArchive. For more information, please contact ellen_amatangelo@byu.edu. 


\title{
GERMAN LITERATURE
}

\author{
SUDERMANN - HAUPTMANN - WOMEN WRITERS OF \\ THE NINETEENTH CENTURY
}

BY

OTTO HELLER, PH.D.

Propessor of thri German Language amb Lrtreature in

WASHENGTON UHIVERETTY, ST. LoUis

$$
(1,1)
$$

GINN \& COMPANY

BOSTON - NEW YORK - CHICKGO - LONDON

$$
2,1,6,6
$$



two brilliant achievements, the existing works of the sort render at most the limited service of catalogues raiconnes, - arranging the facts with different degrees of reliability, and tracing with more or less fallibility the general drift of modem, or, better, recent, literature. For an alien reader, unacquainted with the material unc.er discussion, they are ill adapted. The novice naturally enough is much more interested in the asthetic and ethical maxims of leading individuals and their concrete works than in any abstract creeds and doctrines of the schools. But the "history" of literature, or even of single literary periods, necessarily depends for the characterization of eminent writers upon condensed synopses and brief and usually dogmatic estimates, while for the expounding of the sociological bases from which literary currents ever spring, it must fall back on comment which for the greater part lies beyond the ken of all but the specialist.

Withal the historical method in this field of work is hardly safer from the danger of subjective treatment than is a more frankly "impressionistic" form of criticism. So soon as the "general" reader turns for confirmation of its verdicts to the full bench of critical authority, he is confused by a diversity of opinion which extends even to the estimates of the master spirits of the age. Like less imposing mortals, the historiographer of contemporary events cannot get away from his. own shadow.
The author of this book, not unconscious of the subjective warp in his own judgment, has considered it more to his purpose to show in a series of unconstrained mono. graphs the chief aspects of modern German literature - than to construct a general guidebook for that subject. By dint of detailed analysis he has sought to convey the gist of the two leading writers even to such of his readers as might be debarred from first-hand acquaintance with them.

Just why Hauptmann and Sudermann were chosen to represent the modern tendencies in the drama and in fiction is stated fully in the early part of the first sketch. The paper on Women Writers of the Nineteenth Century, although broader in scope and consequently less intensive in treatment, was joined to those on Sudermann and Hauptmann for the simple reason that it seemed prasical to select out of the fullness of the available mate: just those topics which for people outside of Germany possess the keenest actuality. Should this beginning prove not altogether abortive, it is the author's intention to follow up the present volume with further groups of studies, and he even hopes by this means to round out, less unmethodically than would appear at first blush, the story of the growth, ascendency, and, if signs may be believed, the decline, of naturalism in German literature under the now Empire.

As for the style, or, should that be a misnomer, the linguistic make-up, of these studies, the author, alas, 
may not appease the sternly disposed among his readers with rueful promises of future improvement. Yet the much-tried leniency extended to writers, whether alien born or not, by a public with whom this form of generosity amounts almost to a national fault, relieves him of the need for prolonged apology.

Max, 1905

OTTO HELLER

\section{CONTENTS}

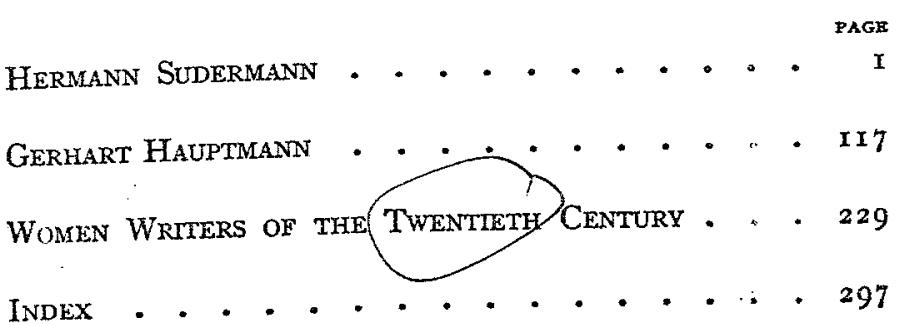




\section{WOMEN WRITERS OF THE NINE- TEENTH CENTURY}

It is the prevailing practice of historians of German literature to maintain a somewhat rigid sapalration of sexes, in their classification of wrivers. There is thus some precedent for the not aitogether philosophic procedure of the present paper, in segregating a number of writers by virtue of their sex for a separate critical treatment. In respect to quantity, the contribution made by women in the field of German letters in the nineteenth century is sufficiently enormous to justify such a segregation. And there is a certain continuity of development running through the whole of it which makes it well worth while to consider the Frauenschriftstellerei of the century by itself.

The general critical judgment passed upon the great bulk of it will not fall wide of this verdict: A startling absence of freshness and originality, counterbalanced in a measure by a great imitative faculty. Naturally we wonder where the cause of the limitation may lie. In Germany it may 
be tixat absorption in domestic interests has been a chief cause for that fatal want of outlook and that seeming incapacity for the fullest self-expression which exclude the greater part of feminine fiction from the legitimate domain of letters. But are the arrested development of the artistic impulse and the atrophy of the higher intellectual powers really to be held alone responsible for the defective literary performance of the German woman? A glance at the writers of other countries gives rise to doubt. In England, George Elict has remained the only great novelist. George Sand has been without a successor in France. And in the United States, where a wellorganized woman-worship has fostered a greater inde:pendence, and where opportunities for education have certainly been ample, not a single work of art of the grander stamp has to this day emanated from woman. Whether, then, there be any nature-ordained limitations which deny to woman the gift of truly creative achievement is a, matter regarding which, at the oulset of this review, we may ask permission to keep our judgment in suspense.

The history of the literary activity of the German woman prior to the nineteenth century, when she made her official bow in polite literature, can be gathered only by indirection, namely, by ascertaining the extent of her influence over literary art. Beyond a doubt there always has existed, under some guise or other, a measure of feminine control over letters. For instance, in both classic periods women were a dominant force: Minnt. dienst (the "service of the lady") is the mainspring: of nearly all German lyrics to the end of the thirreenth century; and even the great epic writers of the Hohenstaufen era are exponents of the chivalric code of love; notably does Tristan unat 'solde breathe its spirit.

Sterner and less romantic times put an end to this feminine influence of the golden age. It reappeared in a more rational form in the course of the eighteenth century. . Womankind has ari unassailable title to our gratitude because of the fact that the discreet censorship which imposed upon the maturer works of our classic writers their wonderful artistic reserve lay in the hands of women. The feminine influence it is that lay also at the root of ideal conceptions like Iphigenie, Leonore, Dorothea, Johanna. The womer of Weimar and Jena, and elsewhere too, represented an extraordinarily fine culture of mind and 
taste. The copious volumes of correspondence of the closing eighteenth and the opening nineteenth century, which are among the most genuine human documents of times intellectually so much alive, disprove finally the self-satisfied allegation that the credit for the advanced literary culture of women belongs to the declining nineteenth century, and is mainly due to America.

But literary culture is not necessarily latent genius.

The imitative character of feminine authorship to which reference was made above is attested by the rush of feminine contributions to every variety of fiction, once its era has been fully ushered in. The misery of the woman of letters deariy loves company.

The performances of the female satellites of the classic writers need not be taken up in this place. A catalogue of empty names and titles would be the only yield. None of them has left an ineffaceable impression. Even the one hundred and twenty-five volumes of fiction by Henriette Hanke - who remembers the name? are incased in solid, impenetrable oblivion. Perchance a passable poem here and there by Luise Brachmann, who leans hard upon the manly shoulders of Schiller, survives. Suffice it to say, in order to gain a starting point, that about the beginning of the nineteenth century feminine fiction came into vogue. Almost immediately it divided into two sorts, between which we have to distinguish to this day. Crudely we may designate these classes as mere amusement novels and novels with a purpose, - a purpose which may be purely artistic, but is, as a rule, educational. It cannot, of course, be said that books of the formes class disclaim all ethical tendency whatever. On the contrary, the authors champion the accepted maxims of respectable society and prepare ther in usum Delphini or rather Delphinæ, since they purvey them to the Backfisch or hookere Tochta the "young person" of Germany. It is fiction of this sort that has attached a rather odious sense to the word Frauenchriftstellerei. Not, indeed, on any moral grounds. For the somewhat sugary , morality of the authoress of this class is unimpeachable, and the most exacting Sunday-school superintendent will cheerfully testify to the - soundness of her religious convictions. Nor is a theory of life lacking, either. It conforms to that benedictory optimism of which Mr. Howells claims to have discovered the ordinary cause 
in an uncommonly well-cooked dinner. Not a drop of bitterness ever makes its way from such a gentle heart to the pen. Bad people, to be sure, there be, presumably for the sake of variety in the color scheme of the universe, and things do have a way of sometimes going wrong. But the lady writer's unalterable forgivingness wears out the most unremitting persecutions of a hounding fate; and to have retribution meted out to him by this sweet soul, the villain must inculge in veritable antics of wickedness. She much more enjoys praying for him, and he, like Editha's improbable burglar, likes to have himself occasionally converted, for a spell. Yet one can ill afford simply to brush aside these "like-motherused-to-make" novels, because a very large portion of our contemporary fiction, here as well as in Germany, is concocted after the same recire, from the same mush and milk, and with the samet weil-greased kitchen utensils. Moreover, it is unfortunately to this class of books that Americans owe their supposed knowledge of the German woman. Externally she consists mainly of a pair of soulful blue eyes, a brace of uncommonly. heavy flaxen tresses, a sweet smile, and a Gretchen bag. Her intellectual horizon is marked out by her accomplishments. She reads and recites Schiller and the expurgated Heine-over hor fine embroidery; she sings and plays - Scinubert, Mendelssohn, and a family sort of Schumann; it remains to say that she knows French and English and is inordinately fond of the approved varieties of flowers. She is the famed angelic maid, the clinging damsel without a backbone whom, according to Helene Böhlau, the Cerman loves so dearly. According to that writer she meets the world with naively astonished eyes, and on the whole manages to have an easy time of it, for a thousand knights-errant are dying to discover her and to make her - make them happy.

Yet in fairness to the Germans it must be said that women of a taller mental stature and a larger temperamental gamut have long ere yesterday stepped in front of this anæmic doll and cast eclipse upon her; and that as a novel-heroine she is now suffered to smirk and simper on the bookshelves of the penny circulating libraries in her own fatherland, or to be translated irto English by Mrs. Caspar Wister.

Let us first turn our attention to the Tendinzschriftstellerei of women writers. Though exceedingly few women have excelled in literature 
by easy mastery of the higher craftsmanship, by that power of intense concentration and seizure of human nature in which the great writer reveals himself, yet many have shown an uncommon intellectual force of the aggressive kind. On the whole, it may be averred without undue exaggeration that nearly all women who play a conspicuous rôle in German letters write in a reformatory frame of mind. And that in a great majority of cases the woman's cause is their chosen field of effort goes almost without saying. It is natural, also, that these spirited innovators ccrne to the front mostly in periods of unrest, when fiction becomes the theater of a heated social warfare. At such times the vigilant woman of the pen contrives under cover of literary exertions to wrest from the turmoil a fresh morsel of liberty for her sex. This helps explain why eren the female adherents of romanticism did not subscribe to the political and religious Toryism into which the movement issued. The emotional Bettrna von Arnim exhibits much of the specifically romantic extravagance of sentiment; and in the greatest virtue of romanticism, the capacity for poetic experience, she also excels. Her more than half fictitious "Correspondence of Goethe with a Child" is certainly one of the finest products of German romanticism. Yet in many of her political and religious views she is in full accord with "Young Germany." Dies Buch gehört dem König ("This Book is for the King") is a bold manifesto calling attention in a marked manner to the starving condition of the Silesian weavers ${ }^{1}$ and blaming a great deal of needless human misery upon bureaucratic quackery.

The active period of Young Germany extended from the Paris July Revolution ( $\mathrm{I}_{3} \mathrm{O}$ ) to the outbreak of the German Revolution of I848. The momentous social forces that were enlisted in the onslaught of this school of wriers against the castle of conservatism lent a practical significance to the cry for the "emancipation" of woman. The Young Germans, accepting the doctrines of the French socialists, and familiar with the writings of St. Simon and George Sand, which had shed a new light upon the civic relation of the sexes, first set up the audacious demand for civil marriage. It reverberates in a.1 keys and modulations through the works of the women of Young Germany, from its sane and clear phrasings by Fanny Lewald to the more

1 See p. 149 of this volume. 
than indiscreet Utopianisms of the Free Love advocates. For soon not only the sacrament but also the civil institution of marriage was put in doub:; so that even radicals were frightened back by the meaning with which "emancipation," now the watchword for the final purpose of the feminine rebellion, was invested by extremists. We see, then, that towards the middle of the century whicl his been called a century of democracy, the r.wing sense of personality permitted the wildest cnarchism to run riot within a regenerative scheme which was essentially collectivist; a phencinenon which makes us question whether socialsm and individualism are not after all but enamations of one and the same fundamental impulise.

The uncontrolled vagaries of the fanatical emancipationist did much to alienate general sympathy from the rational aims of more cleareyed leaders. The "advanced woman" of to-day, were she to study these feminine contributions of the Young German and the subsequent literatures, could not fail to be amazed at the modernness $c f$ the cures for the ailments of society that are advertised. Julie Burow, for example, urges every woman to adopt a trade or a profession for the sake of material independence. And Luise Otto, the founder of the Allgemeiner Deutscher Frauenverein ("General Union of German Women") (1855), even advocates the organization of workingwomen of every grade through labor unions.

We may roughly classify the propagandist fi:tion of the revolutionary and post-revolutionary period according to the great undercurrents that run through its social philosophy, the collectivist and the individualist; in a third class might gathered the writings of the opposition, reactionary either from conviction or from inertia and indifference. But such a simple classification must confess itself far too crude to do more than draw attention to the most obvious distinctions.

The contrast between the main forces within the Young German school is tellingly exemplified in Ida Hahn-Hahn and Fanny Lewald. Their lives reach from the beginning of the century to the beginning of the new era in Germany. Fanny Lewald lived from I8I i to 1889 . Countess Ida Hahn-Hahn was born in 1805 and died in 1880 , - much too late for the good of her literary fame. She had a most tensely eccentric or Byronesque temperament, as they used to say 
in the days of her prime. The experiences of her childhood, her matrimonial misfortunes, her conversion to Catholicism, her brief novitiate in a convent, and other romantic interludes show her personal career to have been so intimately connected with the fate of her heroines that Hahn-Hahn's novels may be considered as links in a long autobiographic chain. From the beginning - Aus der Gesellschaft ("From the Realm of Society") (1838) - she clected German high life as a congenial field, and by vouchsafing her readers the coveted peep into that glittering Vanity Fair she easily attained popularity. In reading Hahn-Hahn you are mace to feel distinctly that you belong to the misera plebs. You have bought a ticket that admits to the gallery only, and are now looking dowr upon the dazzling assembly with all of a plebeian's delight. And as if to show you that your confidence was not misplaced, the noble Countess herself stands at the door below scrutinicing the arrivals and counting their quarterings. No hero passes muster before her unless he is t least a baron and can present himself in a caviry uniform or in court attire. Commoner and civilian are admitted only upon absolute proof of genius, which for the Countess seems to consist of an indefinite expansiveness. A genius, in Hahn-Hahn's estimation, is one whuse soul is capable of "immensity." To everything that is plain, from clothes to character, the lady has an unconquerable aversion. Her faultlessly well-groomed men and her stupendously miliinered women oscillate between ballroom and boudoir as the natural poles of mundane existence. Oddly enough, in this painted and perfumed worid of the formalities, the most startlingly unconventional things continually do happen. The Countess revels in tragedies of the soul - as she undirrstands them. To us of to-day Hahn-Hahn's people, fidgeting forever in their heart struggles, seem somewhat like fishes floundering on the hook, and we regard them without any real human pity. But her books have, in spite of their glaring paradoxes, which are aggravated by a want of the higher technical requisites, a certain fascination in that the morbid subjectivity of the hysterica? authoress is astoundingly revealed amidst all the gorgeous trappings. By virtue of this frankness, and it alone, she is decidedly modern. Countess Ida Hahn-Hahn draws from life and goes to the: mirror in quest of models. Heinrich Heine is 
authority for the statement that the German authoress writes with only one eye on her page, since the other is fixed on some man. It will be seen that his criticism does not apply to the Countess Hahn-Hahn. Her heroines are all of them Countesses Ida Hahn-Hahn: gushing enthisiasts, doting but capricious lovers, fanatical devotees. They are drowned in a sea of emotional conflicts, and the Countess erects for each of them a tombstone with the epitaph: Genius dic it. The modern reader, to be sure, will excupate genius and lay the blame on an impish impulsiveness of temperament. An instance is the fate of "Faustine," the truest reflex of the authoress herself. Faustine tears her bleeding heart from the grasp of her first lover to pass it from hand to hand and finally, for a rest cure, to take it to a nunnery. Her pernicious life philosophy is contained in this rich epigram: "To love is to devote oneself to a single object; but why should that object always be the same?"

Hahn-Hahn, by the strongly individualistic tendency, foreshadows the Herrenmoral rampant in the literature of to-day. That is to say, she is a prophetess of "emancipation" for which the Young Germans, notably Gutzkow and Laube, were striving; but the enlarged freedom is not offered to the men or women of ordinary caliber, the Vielzuvielen of Nietzsche. No; it is exclusively a prerogative of the exceptional person; or, in Stimer-Nietzschean phraseology, of Einzige or der Eigene. Only - this is HahnHahn's personal note - the exceptional man, the great personality, happens regularly to be an aristocrat.

Over against this unreasoned accentuation of aristocratic egotism may be placed the democratic altruism of Fanny Lewald. The sober qualities which make this bourgeoise of Jewish extraction a potent educational factor in the Frauenbewegung (woman movement), render her distinctly unromantic and, it must be confessed, a trifle prosy. The motive power of her convincing eloquence is not a fiery temperament, but cool logic. She is clear and definite, always temperate, and severely judicial, hence the reforms which she advocates are within the bounds of reason. She ponders the same problems as Ida HahnHahn, but with greater impartiality and depth. The tendency of her contemporaries to exempt the genius from the common moral obligations had a formidable opponent in Fanny Lewald. 
She studied the much-discussed marriage question in such a fair and sober spirit that her novel Eize Lebensfrage ("A Question of Life") (1845), one of the earliest and most direct literary arguments in favor of divorce, commanded general attention and respect. Among the earlier champions of the "new woman," Fanny Lewald desurves the first place of honor. Her successful practical activities for the advancement of the cause of women were in full accord with her literary work.

It is only natural that the aims of the radical, women should have stricken horror to pious Protestant souls like Marie Nathusius, the conservative and orthodox authoress of the Tagebuch zines armen Fräuleizzs ("Diary of a Poor Gentlewoman") (1853). This exquisitely "inward" book breathes wholly the humble spirit of obedience which would not meddle with the affairs of the world, believing them safe enough in the hand of Frovidence.

On the Catholic side the projects of Young Germany are viewed with even greater alarm, as, for; instance, by Annette von Droste-Hülshoff (1797-1848), the most remarkable woman writer of her generation, and in the judgment of many competent critics the foremost among all Craman poets of her sex. Droste's real strength, however, does not lie in the defense of her traditional ideals, of which, by the way, she regards George Sand as the arch enemy. On the contrary, the "purpose" in her books, springing from bigotry and a certain religious mysticism, overcasts her artistic clearness and is the very feature that forbids unqualified admiration. For the self-repression in Droste's works is much more than artistic restraint. The mistiness of the composition makes us conscious of her want of outlook. This limitation is compensated in Droste's novels by an uncompromising veracity and rare minuteness of obser,ation, powers which qualified this daughter of the "red soil" of Westphalia to become our first great representative of "regional" art. Still gieater is Droste in her lyrics. They are a fascinating blend of rugged strength of character and delicacy of perception, and reveal an amizing nature-sense which knows how to expres the personality of the meanest object of nature. In reproducing her sensuous impressions of an ensemble such as a landscape, the poetess calls up in the reader novel experiences of nature, in which respect she may rightly be called an eariy 
impressionist, a forerunner of such moderns as Gabriele d'Annunzio.

Likewise averse to the participation of women in public life is another powerful lyrist, the Viennese Betty Paoli (1815-1894). Her poetry betrays rnuch more frankly than Droste's its motive power:

Ich bin nichts weiter als ein Herz,

Das viel gelebt und viel gelitten.

She might have said geliebt instead of gelebt, and sorne nearer to the truth. In poems full of interse yet rather reflective passion she discounteniances all feminine ambition; woman can find her only chance of happiness in love, selfeffacing love. Nature has thus circumscribed her lot, but has at the same time endowed her with $\approx$ power of blissful self-surrender far beyond any which the coarser-grained organization of man is capable.

From these serious writers we must now turn aside for a moment to the two most prolific women writers of the entire nineteenth century, writurs who manifest an attitude of unruffled placicity towards questions of ethical import, of which stoicism the last secret is stolid indifference.
Luise Mühlbach (1814-1873) stood quite apa 1 : from the triumphs and defeats of Young Gr:rmany, although she was married to a prominent member of that school. Seldom before the days of our now fortunately expiring craze for "historical" romance has the vogue of a writer so far outstripped his merits as was the case with Mühlbach. She was certainly not without corsiderable talent; but she was utterly devoid $c$ ? artistic stability, and permitted her ruinously facile pen to run away with her literary co: science. Yet this ungoverned quill-driver had her most loyal readers amongst the culture classes, because her novels were perfectly suites to the shallow taste for historical anecdote that prevailed for a long time after the revolution of I848. As a matter of fact, her characters hat as faint a resemblance to their originals as the mute procession mén in a Shakespearean play bear to the figures they represent: they only paraded in their masks and clothes. Mühlbach's first phenomenal success in the field of historical romance was "Frederick the Great and his Court" ( 1854 ), a novel in thirteen interminable parts. After that, under the spur of increasing popularity, she averaged a baker's dozen of volumes a 
year. The whole field of modern history was canvassed for its backstair gossip. There is hardly a famous personage of the eighteenth or nineteenth century up to Frederick III whom Muihlbach did not cut up and serve up in her literary kitchen. Under her real name (Frau Professor Mundt) she enjoyed in Berlin a reputation as a capital cook and saving housekeeper. But although her domestic economy extended also to her literary work and she spread her heroes thin erough so as to make them go the farther, yet before the hand of death stopped her pen, at the age of sixty, the limited supply had practically ziven out, and during her last years she was forced to rehash the old favorites.

Misfortune never comes single. Charlotte BirchPfeiffer (1800-1868) is the Luise Muihlbach of the German drama. For a true dramatist she lacked the first and last requirement, - the power to grasp character; but she knew how to create an effective rôle. She could not invent a plot; but she had great constructive skill of a certain cheap kind, a perfect mastery of the claptrap of the stage, and absolute control over the facial muscles and tear ducts of the groundling. Her plays fairly drip with maudlin sentimentality.
Withal she was very enterprising. Were she writing in these days, Birch-Pfeiffer might justiy assert her patent to one method of that singular manifestation of our democracy, the theatrical. trust, for she dramatized every popular novel she ficould lay hands on. French and English writers, "such as Dickens, Brontë, Victor Hugo, George Sand, Bulwer, George Eliot, and home novelists, as Auerbach, Spindler, and Schücking, were promiscuously prepared for the stage.

In dealing with these famous authoresses one lapses easily from that dignity which is somehow expected of the literary historian. In extenuation, the Horatian Difficile est satiram non scribere may be pleaded. At any rate, the sum total of the feminine fiction of the romantic and. the Young German era, as well as of that immediately following, is ill calculated to convert the. skeptic. We behold, on the one hand, an agitation which takes its cues from robust masculine minds and in the main retails the ideas of others to the sluggish comprehension of the public: This is done in most cases. without much deference to the dictates of the rsthetic conscience. Nevertheless one significant change is wrough out by the feministic drift of this fiction, namely 
the gradual shifting of the center of interest from the kero to the heroine. Having her frequently exorbitant claims refused in the material world, woman transfers them to the realm of fiction. And so, without any great artistic meaning, the novels which women write and women read and in which women are the leading figures furnish an inventory of the feminine aspirations of the period. A great technical gain accrued to this class of books from the increasing power of character observation and growing zest for psychological inquiry. Little by little it came to be realized that the best judge of the moral organization of woman is woman herself, and when this recogntion was eventually coupled with the analytic skill of to-day, then at last the conditions were ripe under which alone the German authoress was able to seize woman's life in its fullness.

Quite in contrast to the purpose novel stands the huge mass of mere amusement fiction, which has been characterized above. ${ }^{1}$ Throughout the century its output is mainly regulated by the commercial law of demand and supply. By the middle of the century this kind of novel-writing, being then practically the one outlet for the "inteilectual"

\footnotetext{
1 See pp. 235-237.
}

ambition of women, had taken on the aspect of a teachable and learnable trade. Public taste had settled into a comfortable sameness, and from roy on the technical accomplishments of the artisan. novelists were quite equal to the claims made on their talents. The woods of fiction land were peopled by permanent and accommodating settlers. The intending authoress need only shake a tree and down came the baron or officer or professor or artist that was wanted, and the subsidiary ch; $;$ acters were equally obliging in dropping down ready made and just as good as new. Even the plot and the diction were cut and dried. With the aid of the family magazines, among which $D_{i} e$ Gartenlaube and Über Land und Meer marked the highest level tolerated by the "general reader," the conventionalized novel as well as the convention. alized lyric predominated throughout the third quarter of the nineteenth century in distressizo uniformity. But we only have to think of such books as Winston Churchill's The Crisis in order to see what an astonishing success smiles frequently upon works of this order. As for the "tendency," it must not be supposed that the pastime fiction has n't any. We find it wholly concordant with the general way of thinking. The 
grea majority of these writings display a species of mild, dilute liberalism. For after the strenuous agitation set afloat by Young Germany had suffered shipwreck in the disaster of 1848 , its smaller debris drifted peacefully on the shallow waters of ariusement fiction. In this generation it was conceded that women should strive for freedom, but the extent or degree of this freedom was a matter of higgling dispute. So, for instance, the question was raised, What callings are suitable for 3 woman? And it is quite in harmony with the meaning art then had for a writer like Wilhelmine von Hillern, the daughter of Charlotte Birch-Pfeiffer, to conclude that the laurels which grow on the tree of science are beyond the reach of woman, but that she may pluck her laurels lustily from the tree of art; as though excellence in art were less difficult to attain than distinction in science. The "liberalism "of the women novelists shows itself in their incessant war upon prejudices, but they select either such prejudices as no longer prevail, or those which it is safe enough to fight, and, as a rule, their heart is not in the battle. We have refrained from discussing specimens of the outand-out amusement novel in the earlier half of the century. For the period that lies between
I 848 and the great war of 1870 Luise Mühibach was given as a type, although she made pretense to position as an "historical" novelist.

The paragon among German authoresses as they were about 1875 is E. Marlitt (her real name is Eugenie John), who illustrates bitter than she explains the prodigious popularity of a fiction which combined graceful entertainment with easy moralizings, and managed to win applause from the liberals without forfeiting the approval of the conservatives. Goldelse, Reichsgräfn Gisela, Im Hause des Kommerzienrats, Das Geheimnis der alten Mamsell, Die zweite Frau, Das Heideprinzeßchen, ${ }^{1}$ and the other novels which have helped us to while away many and many a dreary hour under the unsuspecting eye of a drowsy teacher, are not without many prettinesses. Marlitt may justly be called an "accomplished" writer. She possesses the gift of narrative glib and voluble; her morals are delightful; she has a knack for the ready and seemingly natural solution of unsolvable problems; and, best of all, she never forgets her manners.

1 The English titles given these books by Mrs. C. Wister are: "Gold Elsie," "Countess Gisela," "At the Councilor's," "The Old Mam'selle's Secret," "The Second Wife," "The Little Mcorland Princess." 
But even the naively admiring eyes of the voracious novel-reader cannot long remain shut against certain defects of Marlitt, though these may stem to him mere specks of imperfection. There is in her stories an engine-turned uniformity of plot and an unnecessarily harsh prejudice against common sense. The reason is not far to seek. Common sense, were it not resolutely suppressed as a factor in her plots, might make itself disagreeable by standing in the way of the all-iswell conclusion required by an exacting public. It is, nccordingly, treated as a negligible quantity, ard the director-generalship of human affairs in Marlitt's novels devolves upon the generous promplings of the human heart. Chief aid-decamp to the noble heart is the irresistible attractiveness of all good people. Whereas in life victories are usually won through powerful exertion. or strong-willed self-denial, in Marlitt the spring of personal magnetism is touched, the good heart does the rest, and stern truth may whistle for it. This successful method could not long remain Marlitt's secret. Once discovered, it was caught up by a swarm of busy imitators who learned the trick though they missed the grace, and to this day their widely ramified sorority flourishes in all parts of the globe. But lest we be diverted too long from our subject, which is, after all, a literary one, let us dismiss the host of Marlitt's satellites with brevity. It is but fair, however, not to make this jejune and time-serving class too inclusive. E. Werner, fo: instance, deserves to be excepted. She adopte: in a general way Marlitt's method of dyeing $i 5$ fine colors. But as a writer she eventually surpassed her model, thanks to a greater breadth of horizon, warmth of conviction, and a certair trenchant critical faculty. Instead of limiting herself to the conventional assortment of heroes, she showed a kindly attachment for misfit ind: viduals; this even betrayed her occasionally int: representing an unmitigated crank as a hero. One might easily mention a number of other popular women novelists of the past generaticn who, like Werner, can lay claim to a high degrie of skill and, without being in any sense grez: writers, wield a good and steady pen at the business. To name only a few, a commendable brisk ness of style marks the stories of Golo Raimunt, Egon Fels, Emmy von Dincklage, and Claire von Glümer. Still more independently gifted are Sophie Junghans and Emilie Junker. 
To none of these authors of the seventies, however, but perhaps to Luise von François, belongs the cistinction of having contributed to the permanent fund of literature the first book of lasting worth. Die letzte Reckenburgerin ("The Last Lady of Reckenburg") presents with surprising realism a picture of patriarchal existence at the end of the eighteenth and the beginning of the nineteenth century. Despite its main shortcomings, which consist in a tendency to preach in season and out of season and the want of outlook so common in feminine fiction, Die letate Reckenburgerin must be assigned a high place among German novels, not only by comparison with the average, but on account of its own unmistakable merit. It is the product of a penetrating, energetic, yet gentle and forgiving mind.

From now on women writers of real worth become much less rare.

An intellect of the same noble type as François' is revealed in the literary personality of Malwida von Meysenbug, whose three volumes of memoirs are replete with deepest human interest, since they are the record of a human soul that has ever aligned itself on the spiritual side of life and has been very close to such eminent men of the age as Richard Wagner and Friedrich Nietzsche. Meysenbug and François beloing to a group of authoresses who are deeply inteilectual and who yet show themselves independent of the "cause," because to them the sole object worth striving for and the one on which they have steadily fixed their gaze, is the fuller development of the idealistic side of human nature.

A like educational aim, ever consistently ideaiistic, inspires the work of Marie von EbnerEschenbach, who, now in her seventy-fifth year, belongs on the whole to the older literary school, but has in some ways exercised great influence over the present generation of authoresses. She enjoyed a rather modest renown before the arrival of the new era, but once the amiable superficiality of Marlitt had begun to pall, Ebner-Eschenbach's depth of feeling was hailed as a welcome relief. She is now looked upon by some critics as the foremost novelist of Germany, and by general consent is recognized as one of the best shortstory writers in the world.

Marlitt and her followers derived much public approbation from their "idealism." Marie von 
Ebner-Eschenbach is an idealist of a much more substantial sort. She is deeply in earnest and permits herself no dalliance in philosophical problems that are beyond her depth. A rare gift of self-criticism is coupled in her with a freedom from prejudice that is almost startling in a member of the high aristocracy. Inborn goodness and the large-mindedness bred of wisdom are the chief elements in the thinking and forgivirg morality of her works. In her stories each individual is permitted to struggle in his own unhackneyed way with the problems that beset the path of life, but the course of fate is not deflected by any silly shrinking from an unhappy ending. The guiding hand of the authoress shows only in that the outcome invariably vindicates the higher ethics. That is because she herself stands unswervingly for the Hellenic and Goethean ideal of Sophrosyne. This philosophic temperance explains the full meaning of her trivial-sounding motto: Gutsein ist Glïck. Such high personal qualities are only too apt to put the critic off his guard when it comes to judging the artist in the superior woman. It is at this point that many a thinking reader will feel

\footnotetext{
I By birth she is an Austrian countess.
}

constrained to part company with the chorus of eulogists. He will not deny at all that Ebner's writings mirror, as has been aptly said, "the conscience of a priestess and the heart of a mother." But he will often miss the distinctive art rote. 'Ebner's composition is apt to be crude or labored; her diction is refractory; in nearly every story a didactic elevation of the voice disturbs the harmony; and as for her realism, it is wholesome and unstudied, but touched up too highly with romantic tints to be convincing. Yet she may claim for her eclecticism as much of truth ass is obtained by the "naturalists," for her endeavor, so she tells us, is to reproduce convincingly what she alone has seen: "a noble feature in the face of the outcast, or a flash of genius in the dullard's eye." Marie von Ebner-Eschenbach, to be a writer of the first order, lacks two essentials: a deeper sense of beauty and greater possibilities of temperament. But taken all in all, she is an eminent literary character with a forcible and steadfast individuality of her own.

François, Ebner-Eschenbach, and Meysenbug, although their writings derive their value in part from their pedagogical message, do not pay any particular attention to the woman movement, 
which, as we saw, stirred so many minds to their depths towards the middle of the century and, after ebbing away in the sands of the later amusement fiction, was to leap forth with fierce vigor in the feminine writings of our own day. The lives and works of these authoresses reflect the waning light of a day aglow with the rich and mellow culture of the Goethean age. In connection with them should be mentioned Carmen Sylva, the Queen of Rumania. She combires the mature temperance of Eschenbach and Meysenbug with the greater intensity of the modern school. To a greater extent even than Marie von Ebner she is a reflective writer. Following W. Jordan's example, she boldly makes the modern scientific theory of the world the intellectual content of her work. As the result of earnest study of social and religious problems her stanch but by no means uncritical optimism stands on the lofty level of an ardent faith in natural evolution.

Having, after this hurried retrospect, now reached the threshold of the present era, we next pass on to a group of younger writers, real transition types that usher in a rather hysterical cultus of art and the artist.
Ada Christen, Ossip Schubin, and Maria Janitschek are all three Austrians, but though not untinged with the easy-going, sanguine temperament of the modern Phaaces, their conception of life, on the whole, is dismal enough to suit the most stringent pessimist. This fundamental dolefulness sounds most genuine in Ada Christen, the oldest of the trio. Of the same age with Carmen Sylva, she is grouped with younger writers because she has even more in conmon with them than the Queen of Rumania. Her impassioned verses in many respects remind one strongly of Betty Paoli, save that Christen's selfrevelation is much more thoroughgoing: her poems conceal and disguise nothing. It is a far cry from the unreserved candor of her $L_{i} e^{-}$ der einer Verlorenen to the pathological "exhibitionism" of Marie Madeleine's Auf Kyjros and the lyric confessions of Else Galen-Gibar. And yet, for good or for evil, Ada Christen first broke the seven sacred seals and bared undivulged feminine secrets. This unrestricted subjectivity is, however, not the only quality wisich puts her in a class with the "moderns"; she belongs there likewise by her harrowing naturalism in depicting the proletarian miliez. This is 
true both of her verses and her stories. Nevertheleis;, the famous Viennese humor does not fail her, and some of her homely good-natured stories of Viennese life are veritable cabinet pieces; for example, Echte Wiener ("True Children of Vienna"), the story of Waltz King Strauss' boyish infatuation for the mother of the authoress. Ada Christen fully appreciates the quick and lively freshness of Viennese life, yet she grasps the fact that at the root of its artistic laissaz faire there lies the shallow self-indulgence of the philistine. And in some of her gloomsteeped stories she shows how the native joyousness of such people is overspread by darkening sorrow and finally put out by despair.

Thite earliest specimens of the work of Ossip Schubir. (Lola Kirschner) were full with the promise of great things. They gave evidence of a strong though undisciplined native talent, uncommon dash, a quick power of observation, and showed a keen knowledge of two opposite world:a, high life and the peasantry, truly astonishing in a youthful person and an outsider to both. Ossip Schubin made her literary début at sixteen, and set out on her career with the cheering approval of George Sand and Ivan
Turgenieff. But as time went on and popularity gave her assurance, she seemed to neglcct her further artistic education. At any rate s.ie has yet to make good her extraordinary promise. Her present style of writing is calculated to strengthen rather than disarm the suspicion that Ossip Schubin bears some unfortunate affinity to Hahn-Hahn. Not alone in her controlling weakness for international high life; for she is, besides, self-conscious and given to mannerisrns - take the polyglot titles of her books - and sensational effects. With the naturalist tende :cies she is, on the whole, out of touch, althoug? at the outset of her career she showed a stror $\mathrm{s}$ leaning towards realism; and although herself quite outspoken in dealing with those subjects which were formerly tabooed in feminine fiction, she has no patience with the extent to which the ruling freedom of speech is made use of $b y$ the latest generation of women writers.

This brings me to a feature of the new feminine fiction which even here cannot go wholy unmentioned. The quality for which above il others the German reader was once accustomed to look in the works of women, namely, that maidenly modesty which for sweet souls like 
Ottilie Wildermuth and the enterprising Elise Polko still proves such a sure pathfinder to the Christmas tree of the boarding-school miss, is no longer sharacteristic of the authoress. Extremes often meet. Our women novelists were at one time squeamish. They are now frank beyond the frankness of Amélie Rives-Chanler and Ella Wheeler Wilcox, frank to the very limits of brutality, nay, even to the extent of sometimes oversiepping them.

The serious student of literature must not be prudish. But though callous to those transgression's which bring down upon many excellent books the condemnation of our public librarians, aven he will be nonplused by the unbridled candor of Maria Janitschek. He will shrink from it only the more because it struts along in pontifical robes. Maria Janitschek came into prominent notice in the early eighties of the past century as one of the first exponents of "modernism." Her chief characteristic is an emotionalism strangely mixed of "mud and fire." On the one hand, she revels in erotic problems of the most risqué sort, dealing with them in a manner of the earth earthy. On the other hand, she is a fanatical votary of symbolism, with a passion for all that is abstruse. Like very many modern Cerman writers, she is also a priestess of the greatest mystification of the nineteenth century, the $\ddot{U} 6 e r-$ mensch-cult established by Friedrich Nietzsch:.

The number of Schubin's and Janitschek's satellites is legion. Their names, however, are hardly ever heard out of Germany, except possibly that of Hermione von Preuschen, who may be known in this country, at least as a painter, for her "Mors Imperator" was a conspicucus exhibit in the Woman's Building at the Columbian Fair in Chicago. Her writings are as coquettishly mystical as her pictures.

The foregoing synopsis, aiming only at a sug. gestive and helpful classification, has assumed that a modicum of familiarity with a few of the more conspicuous writers who served as illustrative examples could be taken for granted. Many of their works are accessible in English translations. But now that the critic is at last led into the company of the German woman of letters of to-day, the widespread though unpardonable American ignorance of contemporary German literature confronts him as a serious difficulty; an ignorance which is doubly deplorable on its own account and on account of its 
causes. This expression of regret does not imply that is is worth while for any one in these busy days to try to keep up with the entire literary prodution of two continents, with the British Isles thrown in. But a legitimate human interest attaches to whatever part of modern fiction is actually conjured up by the living forces of our time; especially to so much of it as reveals the passing attitude of one generation of men towards the basic principle of society, - the universal moral law. Whatever may otherwise be urged against the new novels and plays of continental Europe, it must be admitted that they have justified their claims on human sympathy by an astoundingly close touch with all sides of life There is every reason in the world why the literature of to-day should reflect a greater wealth of experience and contain a fuller register of ideas than that of any former period, even though literature has been unable to keep step with the miraculous expansion of the practical activities. Indeed, when viewed from the culturehistoric standpoint, the work of living German authoresses is thoroughly worthy of attention. Howaver, there are very few subjects on which wen the American woman, superior as she is to her male compatriot in literary as well as in general culture, is so densely ignorant. The reasons are not far to seek. Notwithstanding her ample educational advantages, the American woman, as a rule, is a poor linguist. To enjoy a book or a play in the original, one must at least be beyond the need of continual reference to the dictionary. Yet there are many otherwise well-educated American women, perhaps just out of college to-day, who are unable to make out a fairly simple German or Frerch text. This is to be lamented, even though the assertion of a living French critic, that to declare oneself unable to read German is to confess oneself at least twenty years behind the times in knowledge, is undoubtedly an exaggeration. Persons unfamiliar with German or French are very likely to invoke by way of excuse the whimsical saying of Emerson, that he would as soon swim across the Charles River to get to Boston, instead of crossing the bridge, as he would read a foreign original when he could obtain a translation. It may be said, in reply to the Concord sage, that it pays to learn swimming, even apurt from the healthful excitement of the exercise. For there are some very wide rivers that are 
spanned by too few bridges. Such an one is German literature. Now, it may be asked, how does it come that so few specimens of German "modernism" are made accessible to us through translation? Possibly the explanation lies in the nonconformity of these audacious Germans to out tacit exaction that foreign writers should pay court to our jejunely nice, scrupulously conventionalized literary taste.

The most potent influence that is at work in the German literature of to-day partakes of the nature of a grimly resolute striving for the fullest individual freedom. The effect of the new rebellion sown by the daring genius of Nietzsche is clearly manifest in the turn taken by the plea, in fiction, for the woman cause. The rights of pe:sonality, which were formerly subordinated to considerations of the general welfare, are now londly emphasized. The leading women emancipators of to-day extol the "creative" life above the life sanctioned by social agreement, and do not question the right of the individual to break through the accepted moral formulas. They utterly reject the gospel of patience, which wornen love so much to observe and still more to preach. And while the old accusations of tyranny are still hurled against the ruling sex with the undiminished vigor of old, not a little criticism, intemperate and sometimes savage, is directed against the meek and stolid submissiveness of the women themselves. There is a degree of danger in this fanatical agitation for unchecked liberty, and it cannot be denied that such teaching may prove fatal to a few unsteady heads. There are two ways of dealing with such a situation. In this country, where literary fashions bow to the dictate of public opinion, we choose to suppress the dangerous doctrine by smothering its utterance in fine indignation. In Germany, on the other hand, the fullest discussion of heterodoxy is freely tolerated. The Germans realize that progress in culture can only spring from a soil constantly plowed up by controversy.

It seems to me, then, that we are committing a grievous error in denying a hearing to what the most capable women of Germany have tc say on a subject which to them is of the greatest moment, even though we may feel that their zeal is greater than their insight. After all, she heroes and heroines of recent German fiction, for whom ruthless self-affirmation is claimed as 
a special prerogative, are not of the common run of people, but of a class scarcely extant amorisst us; they are nearly always artists. And surely we need have little apprehension lest our own types of the overman, the trust magnate and the political boss, catch the infection and apply their overgrown sense of individuality to a sphure other than the material. Candidly, so long as we admit to our homes the "yellow" daily: it is hypocrisy on our part to proscribe any seriously meant book or class of books in the rame of public morals.

The literary era that dates from the early eighties of the past century and is commonly called "Youngest Germany" has been more fruitful of good than of evil. Whatever may be our judgment as regards its ethical merits, it has brought us a most gratifying progress in all technical respects. Though the successors of Marlitt in and Dut of the Gartenlaube still jog along imperturbably in the old ruts - St. Keyser, W. Heimburg, D. von Spättgen, F. Kapff-Essenther, H. Schobert, e tutte quante,-yet even their banal plots with their never-failing happy dénouement have profited by the modern example. As for the writers of the new school, any fair-minded person must admire in them a great strength of purpose and power of observation, a wider range of sentiment and opinion and a more piercing artistic vision than were given their predece:sors. And while the modern woman of letter: might perhaps resent this congratulation, there is cause for rejoicing in the fact that the gratify. ing literary improvement has gone hand in harci with the steady enlargement of woman's sphert and opportunities.

In unabated agitation of the woman cause, Gabriele Reuter and Helene Böhlau stand preëminent. Both strike out boldly for a fuller liberty. but they also seek to deepen the sense of woman towards her new obligations. Reuter's famous novel, Aus guter Familie ("Well Bred"), pleads in spirited fashion against coercion in every form whatsoever; by insinuation, the authoress includes marriage, an institution devised by the despotisn of man and acquiesced in by the slavish cowardice of woman. The slender thread on which Gabriele Reuter strings her moralizings is the tragic story of Agathe Heidling, the daughter of an official. Like all girls of her class, she is brought up primarily to marry; failing to do this, she settles, after a brief rebellion, into a purposeless life at 
the cost of her true personality, and, finally, of her reason. Incontestably, this book, of which the lession is self-evident, has proved a powerful lever in the hands of the radical advocates of social reform. Its plea, as is the custom with such books, gained the day not so much by the persucsiveness of the argument as by virtue of its glittering eloquence. Few "novels of purpose," it should be borne in mind, do make their way by means of intrinsic worth; most derive success from vociferation.

Helene Böhlau is no less emphatic than Gabriele Reuter, but very much more forcible. She, too, enjoys writing "at the top of her lungs"; yet even though she has not held aloof from sensational exaggerations, - notably in Das Recht der Nutter ("The Mother's Right") and in Halbtier ("Falf Beast"), - she is the greater artist of the two. Two entirely different groups of novels have come from her pen. The earlier ones, incited by a close touch with Goethean culture - Helene Böhlau yrew up in Weimar - radiate a sunny humor, but bear not at all on vital issues. Later on, Nietzsche supersedes Goethe as Böhlau's lodestar. Henceforth she extols the new, intoxicating passion of life that makes a demigod of him who will desert beaten paths and, with a new-won consciousness, gain the power of wresting joy from each phenomenon as it reveals itself anew. This sovereign power, to Nietzsche and his disciples, is the sublimated life which alone is worth living. An almost sacred wrath against the meager contentment of the female philistine as well as against the rapacity of her male tyrant burns in Böhlau's intemperate harangues. Forever she harps the plaint of Iphigenie in Tauris: Der Frauen Zustand ist beklagenswert. In Adam und Eva or Halbtier she maintains that womar such as she has become through the enforced disuse of her spiritual faculties is not yet a completed human being. This shows itself, among other ways, in her pitiable impotence when brought face to face with adversity, "If a beast. were hunted as woman has been, it would de-; velop a weapon - a horn perchance, or a venomous tooth. Not so woman. She has only grown tamer and tamer, disgustingly tame, and has become in the veriest sense a beast of burden. Her direst wants have been neglected. If she has obtained a small part of her rightful inheritance, the has done so with the cunning of a famished beast - by stealth and subterfuge." Every blow 
prostrates her, leaving her unsustained by the consolations of the mind. Woman, according to Böhlau, is a human body which passes through life entirely unspiritualized. And that half of mankind which they call the gentler or weaker sex is, in truth, the robust, the coarsely materialistic inimical perforce to all that is lofty or subtle in our existence.

Fortunately for woman, so Böhlau holds, her relertless persecutor, man, is singularly naive in his :udgment and not at all hard to suit. All that he expects of her is that she should make herseif as nearly as possible like the ladies he admires on the front cover of the German family magraines. But the strong-minded Helene Böhlau scorns and hates the easily pleased despot and marks him with a fiery cross, by way of a warning to the sisterhood.

A side perhaps from her faith in the possibilities oi womankind, Helene Böhlau is a thoroughgoing disciple of Nietzsche. As such she sets her face against the prevailing mope-eyed conception of human destiny which takes the form of either complacent optimism or indolent pessimism. To her way of thinking, the culmination of the fuller life lies in its supreme moments, be they moments of achievement or defeat. George Eliot once expresses a similar sentiment when, in The Mill on the Floss, she says of the heroine as she nears the climax of her fate: "Even the coming pain could not seem bitter - she was ready to welcome it as a part of life, for life at this momeat seemed a keen, vibrating consciousness poised above pleasure or pain." And Ricarda Huch, in a poem, says to Life: Denn du bist süfs in deinen Bitternissen. It is a maxim with Böhlau that every true personality contains the possibilities of a self-determination that should bring either crowning success or destruction, should lead either to unmingled happiness or - to pure Lahappiness.

\section{But -}

Every deed of ours, no less than every sorrow, Impedes the onward march of life.

Some alien substance more and more is cleaving To all the mind conceives of grand and fair. ${ }^{1}$

In the humdrum grind of our daily existence, which is bound sooner or later to shatter the exceptional individuality, the human tragedy is adulterated.

1 Goethe, Faust, translation by Bayard Taylor. 
It will be noted that the writings of Helene Böhiau, although she is a realist as regards the striking reproduction of the milieu, are steeped in the azure of idealism. Naturally enough she takes by preference artists for her heroes and, like a majority of the novelists of to-day, seeks her models in the "Athens on the Isar," the center of the "new art," Munich. This is true both of Halbtier and of her most important book, Der Rangierbahnhof ("The Switching Station"), certainly one of the greatest novels of recent times. The plot of this story, again, is made to subserve the writer's ethical creed. Its central figure, Olly, burns up with an inner fire which she cannot communicate to the surrounding world. Her family, including a well-meaning but commonplace and selfish husband, cannot understand her, and her inner self is, as it were, placed on an insulating stool; but at the last, when her wasted young life is fast slipping away, the companion soul of the great artist friend stands revealed before her and she dies contented. The resemblance of this story to that of Marie Bashkirtseff and BastienLepag is unmistakable. Yet "The Switching Station," as may be inferred from the very title, should in the main be understood symbolically.
Many of our stanchest realists are to be found in the downright symbolist school. Strange as this fact may seem, there is assuredly nothing contrary either to nature or to art in a method whereby the externals are seized for the presentment of the larger truth. But symbolism somehow carries within it the germ of exaggeration. Even Ibsen, the master in combining the two methods, succumbs occasionally to the danger, and falls into an excessive symbolism, as, for instance, in "When We Dead Awake," where the principal characters are little more than allegories mounted on human legs. It is on these same shoals, $\mathrm{soo}_{\mathrm{B}}$ that Böhlau's imposing art is more than once seen to founder.

Then, too, her artistic equipoise is disturioed by her strong desire to retaliate upon the enemy of her sex. Barring a few rather freakish overmen, all specimens of the masculine gender that appear in her late novels are either hopeless reprobates or invertebrate ninnies. The iniquity of man is concededly great and his villainy deepdyed; when overdrawn by a feminist they border on the grotesque.

It may be pertinent in this place to call atterition to a significant change wrought out in these 
days: the feminine literature of to-day is an integral factor in the general intellectual life; it consequently shares in the literary evolution. Recent German fiction has emerged from the era of uncompromising realism with a zest for psychological inquiry, and in the natural order of things women become more deeply inquisitive about themselves. At the same time they realize more fully than before their special gift and superior aptitude for detailed observation, and to their minute and honest account of themselves we on e an enlarged knowledge of woman's character. But in the reformatory zeal which impels our women writers to redress the wrongs of their sex, the great human problems under discussion do not receive sober study, and so we find that even a writer of Helene Böhlau's stature seems shut out from the loftier outlook from which the true poet views the eternal pantomime.

At the present moment the most conspicuous German authoress is undoubtedly Clara Viebig. She is the leading apostle of the anti-emancipation doctrine of Laura Marholm, - the doctrine that woman is but a fragmentary work of nature, and needs to be completed by the union with

1 Cf. p. 60. man. Yet in spite of this theory, Viebig exhibits in her style a rugged, virile strength. In her masterly village stories, Kinder der Eifel ("Children of the Eifel"), and in the grimly humorous novel Das Weiberdorf ("A Women's Villary"), she uncurtains with a pitiless hand the brutalities of peasant life. Das tägliche Brod ("Daily Bread") is a deeply serious study of the ser,rant problem under aspects which to Americans will seem stranger than fiction, they are so diffe"ent from our own. "The Watch on the Rhine" is a veritable triumph of the Heimatkunst ("regional art") so assiduously cultivated by the Germans. The latest of Viebig's literary performances, the novels Vom Mïllerhannes ("Jack the Miller") and Das schlafende Heer ("The Sleeping Army") and a dramatic suite entitled Der Kampf wm den Mann ("The Fight for a Man") - all tree published within the last two years - are keeping her prominently before the public.

Though overshadowed by Böhlau and Viebig, yet there are many other forceful writers in the younger generation, - women full of indomitable energy, deep convictions, in some cases equipped with a fine technical skill. Only a few of them can here be mentioned. 
Anselm (Selma) Heine is, like Helene Böhlau, a realistic symbolist who likes to deal with problems from the artist's sphere. She teaches, among other things, that the higher individuality is put in jeopardy by a too congenial marriage.

With a telling protest against the ruling conventions are fraught the plays and stories of Anna Croissant-Rust and those of the unfortunate Juliana Déry, who sealed her dissension from the accepted social code with a tragic death. Emil Marriot (Emilie Mataja) varies the theme by tracing the real "soul" tragedies to religious conflicts. She is a devout Catholic, yet has a predilection for the very delicate subject of clerical love with which the consummate art of Paul Heyse has dealt in Zwei Gefangene ("Two Prisoners"). In the series of short stories, Mit der Tonsar ("Tonsured Heads"), the principal characters are priests who are unhappy through love. Perhaps the best thing she has written is the stirring prose threnody Der Geistliche Tod ("A Clerical Death").

Marie Eugenie delle Grazie is a poetess of unquestionable power, but lack of artistic discipline renders her unequal to the great tasks she elecss. In her epos "Robespierre" - she is one of the relatively few women who have attempted epic poetry - she demonstrates that even the rnost terrifying realism is not proof against the noisy sort of emotionalism.

Under her pseudonym of Leo Hildeck, Leonie Meyerhof has made a well-known name for herself. In Wollen und Werden ("Purpose and Achievement") the artist tragedy turns on the discrepancy between the creative impulse and the sustaining capacity for work. Hildeck is an enthusiastic Nietzschean, and the prototype of her Feuersäule ("The Pillar of Fire"), notwithstanding her express denial, can be none other than Max Stimer, the forestaller of Nietzsche. For her entirely un-German coldness, this writer compensates by a rare constructive skill.

Lou Andreas-Salomé, the biographer and onetime friend of the great poet-philosopher-madraan, deals in a bold, broad manner with intricate psychological subjects, such as the baleful awakening from juvenile illusions, dwelling strongly on the necessity for deep religious sentiment.

The two most promising among the youngest set of German authoresses also follow undoubtedly in Nietzsche's footsteps. The youthful Sophie Hoechstetter is so deeply engrossed in

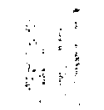


the propagation of the individualistic creed that she has taken no time to bestow great care on the form of her writings; so her rebel pen does not disdain the handy style and methods of the amusement novel, even though in the interpretation of the master Zarathustra she exhibits a greacer freedom of thought than most other disciples.

A. even more resolute agitator and by far a more convincing "realist" is Hans von Kahlenberg, whose real name is Helene von Montbart, a young woman belonging to the circles that are styled Mititäradel ("military nobility"), and whose novels move accordingly in the higher strata cf German life. It would not be easy to name a writer of either sex so entirely unsentimental as Hans von Kahlenberg, or one with a finer ear for the hollowness of "official morality" and a keener eye for the sores that eat their way through the German body social. Upon these cancerous spots she advances composedly with the surgeon's blade, which she wields in no gingerly way and without first administering anæsthetics. Though only in the early thirties, she is already a master of the naturalistic method. The crassness in the portrayal of her milieu
- e.g. Die Familie Barchwitz ("The Barchwitz Family"), Die Sembritzkys ("The Sembritzkys"), and other novels - may be easily condoned in view of her deep sympathy with the sufferings of her people.

The enumeration of the authoresses of this combative Nietzschean sect might be continued to great length. The aim of this sketch, however, cannot be completeness, but at best an indication of salient traits, and enough has been said to substantiate the statement made before with regard to the predominant influence of Nietzsche on our feminine literature of dissent.

Two writers who represent the high-water mark of artistic achievement by German authoresses of the living generation have been reserved to the last. Neither can be classed as a Nietzschean of strict observance, and neither can be called a thoroughgoing realist, or a pedantic symbolist. But to elude classification is to give the sincerest proof of a self-dependent artistic personality. Isolde Kurz and Ricarda Huch come well up to the test. Not uninfluenced, certainly, by great models, but without looking right or left to schools and coteries, they kave made their way to the front rank. They are 
artiste, frrst and last, who have learned to employ the technical acquisitions of the modern school for the presentment of facts under their eternal a.ject.

Of the two, Isolde Kurz is perhaps the more versatile. She commands a style which is scarcely surpassed by Paul Heyse when at his best. Her poems, and in a still higher degree her short stories and satirical fairy tales, besides excelling in a chaste plastic beauty of language, win by their rich fund of ripe human wisdom and an irresistible humur, delightful even though spiced with cutting sarcasm, of which the reader himself is frequently made the mark. The extraordinary strength of Kurz's art lies in its burrowing psychology, by which the subtlest qualities and corritions of mind are brought to light. This rare power enables the writer to expose with sensuous truthfulness, "realistically" as it were, the world of the unreal. To quote an example, the story Mittagsgespenst ("A Midday Specter") reproduces with great vividness a weird daydream of a medixeval city in the full fierceness of its tempestuous life. Italian life, especially that of the Renaissance, has the same charm for Isolde Kurz that it exercised on her great teacher, Conrad
Ferdinand Meyer. Her most serious contributions to letters, besides a small volume of exquisite lyrics, are two collections of short stories: Sho rentiner Novellen ("Short Stories of Florence") and Italiewische Erzählungen ("Italian Tales").

Of still greater artistic significance is the work of Ricarda Huch. It detracts in no wise from the marvelous originality of her art that it has been influenced by Gottfried Keller and Conrad Ferdinand Meyer, and that it, too, has been electrified by a spark from Nietzsche's wayward genius. The last-mentioned influence is recognized in her favorite heroes. They are the Lebenskiunstler, the past masters of the art of living, modern Renaissance men and women with a capacity for translating great emotions into action. Huch, at the age of thirty-eight, is the author of fifteen books comprising two metrical plays, two ccllections of critical essays, a historical study, a book of poems, and nine volumes of fiction. All of these are works of intrinsic value. Her chicf title to fame, however, still reposes on Erinnerungen von Ludolf Ursleu dem Jïngeren ("Recollections of Ludolf Ursleu the Younger"), a book full of the indefinable charm exhaled only by what the French call une cuure de longue haleine; one of 
thrse rare books, that is to say, which draw the reader into the very mood in which they were conceived and sustain him in it. The novelist whose unerring art has given him supreme power of this sort is Thackeray. By virtue of their temperamental consistency, Pendennis, Henry Esmond, The Newcomes, are unsurpassable models. Du Macrier's Trilby owes its unquestionable value to clo;e and successful study of those great models. Ariwng living writers, Pierre Loti and Maurice Maeterlinck, by an almost hypnotic power, communicate to the reader their own minor-key temper of mind. Ricarda Huch attains similar effects without the aid of chiaroscuro. At least in Ursleu an Lins der Triumpingasse ("Stories from Triumph Lane") she draws in the broad light of her own dxy. As a rule, however, she makes the color perfection of her picture stand forth more distinctly by incasing it in an artistic frame of chaste design. It is no easy matter to adapt, as Huch has done, the style of an old chronicle to a recital of contemporaneous events. But Huch's vigorous art does not choose the line of least resistance. Aitogether she compels the highest admiration for her firm conscientiousness in squaring herself with technical difficulties and exactirg from herself heroic tasks. It is characteristic, perhafs, that her most ambitious works are by far h:r best. Whereas the short stories fall appreciably below the high standard by which her superlative art deserves to be marked, her two master ncyels, by virtue of their flawless structure, excel even Keller's famous Der griine Heinrich ("Green Henry") and take elevated rank with the lofty achievement of Conrad Ferdinand Meyer's imperishable prose epics.

The "Memories of Ursleu" purports to be written in cloistered solitude by the sole represent $\begin{gathered}\text { tive } \\ \text { tive }\end{gathered}$ of a headstrong race whose members, notwithst:nding their imperious vital instincts, are doomed to self-destruction by their unbending will. In the unraveling of the plot a most skillful use is macle of episode, for the double purpose of enlarging the historical vista and, at the same time, maing the private tragedy stand out in bold relief against the general calamity. The action passes in the republic of Hamburg during the cholera epidemic of less than twenty years ago. The plagte is not broadly pictured as in Manzoni's I Promessi Sposi; rather with the delicate discretion used by Boccaccio in the framing of the Decamerone. The "Band of the Holy Life," into which yourg 
patricians of both sexes form themselves in order to vindicate amid the surrounding horrors of death the joy of living, serves as a symbol for the chief tenct in Ricarda Huch's philosophy: life is not worth living without the illusions; hence let us cling to the illusions. No need of saying that Ricarda Huch is not a "realist" in the pedantic acceptation of the term. Yet she knows well how to reproduce the milieu of the patrician life as well as-in Aus der Triumphgasse-of the slums; and she possesses the highest credential of her art--style. Le style c'est-this time-la femme! Huch's is a personality with apparently unlimited possibilities of inward experience and a coextensive power of articulation,- herself a member of the "Band of the Holy Life," with a passionite desire to taste of the choicest dishes at the banquet of life. Unersättlich ("Insatiable") is one of her finest poems which gives adequate expression to this longing.

Ganz mit Frihling und Sonnenstrahl,

Klang und duftenlem BlitenguS

Mein verlangendes Herz einmal

Fiull' mir, seliger Überfußs!

Gib mir ewiger Jugend Glanz,

Gib mir ewigen Lebens Kraft,
Gib im fluchtigen Stundentanz

Ewig wirkende Leidenschaft !

Aus dem Meere des Wissens laß Satt mich trinken in tiefem Zug!

Gib von Liebe und gib von $\mathrm{HaB}$

Meiner Seele einmal genug.

With this cursory characterization of the most important German women writers of the hour this sketch may be concluded. It goes without saying that many deserving books have necessarily been left undiscussed, and that of many well-known authoresses even the names could not be mentioned. To furnish a handy reference catalogue was not the reviewer's ambition, and an appreciation of writers like Klaus Rittland, Hermine Villinger, Charlotte Niese, Elsbeth Meyer-Förster, Richard Nordmann, etc., or even the terse and forceful Ilse Frapan, would neither have affected the general estimate nor made a perceptible change in the line of development as traced. The same consideation justifies the omission of Bertha von Sitt. ner's Die Waffen nieder! ("Down with Armsi"), which owes the international applause bestowed upon it solely to its humane sentiment. The book, it will be remembered, is a plea for general disarmament. Its literary value is slight. The 
chronological limit of the theme precludes more than passing reference to the so-called "Vera" literature, which has rapidly crystallized round the recent anonymous diary of a young Viennese girl who announces herself in the title, Eine fiir Viele ("One for Many") as the spokeswoman of a numerous class; to the Baroness von Heyking's Brieje, die ihn nicht erreichten ("Letters that did not reach him "), and many other books. It may be of some interest to know that Ernst Georgy's Die Berliner Range ("The Berlin Hobbledehoy"), a phenomenally popular series of cheap-grade funbciks, comes from the pen of a woman.

The writers here considered have been, with very few exceptions, novelists. This is natural encugh, since in the field of the prose epic, which throughout the nineteenth century has been the most diligently worked of all literary fields, the authoresses have, as a rule, exercised their talents. In the other literary genera they have produced relatively little that counts for much in the history of literature. Lyrists we have in plenty, and a number of them are worthy of praise, as, for instance, Anna Ritter, Agnes Miegel, Mia Holm, Alberta von Puttkamer, Thekla Lingen, etc. But, outside of the women lyrists who have been discussed, it would be difficult to mention any whose verse rings full and true, and sounds the note of a deep poetic conscientiousness. Certainly we cannot pay this tribute to Johanna Ambrosius, about whose sympathetic songs so much ado has been made. She is a plain, sensible peasant woman whom Professor Weiss-Schrattenthal, the benes:lent patron of aspiring authoresses, had the questionable taste to dress out as a species of German Sappho and to have presented to the public by her East Prussian countryman Sudermann. Thirtysix editions of her poems were exhausted in four years, yet even that phenomenal book-trade success will not keep her memory alive. Ambrosius has clearly been overrated. She has opened to view a soul-life of great depth, but of inccisiderable compass. And she is too well read in devotional books and family magazines to have preserved the refreshing spontaneity of a genuine singer of the people. Lyric qualities of a much higher order belong to Marie Madeleine, whe is unfortunately the most brazenly unabashed of all modern verse writers.

In the province of the drama the successors of Birch-Pfeiffer have not made many briliant conquests. Of living women dramatists, Elsa 
Bernstein, who writes under the assumed name Ernst Rosmer, is the only one who has won real distinction. The singularly happy combination of realism and romanticism in her fairy piece, Die Konigskinder ("The Royal Children") (1895), has done much to establish the reign of the Mär chendran $a$ ushered in by Hauptmann and Fulda.

On the whole, women have shown a certain ineptitude, or it may be only a reluctance, to essay literature under the restrictions of definite form, and have exhibited a leaning towards the less exacting prose narrative. And, as a class, women novelists have their pronounced failings. They are found lacking in the calm objectiveness that flcws from historic consciousness, and in a well-bulanced sense of personality. Likewise, we feel strongly, in their interpretation of detached facts of life, the absence of a controlling philosophy; simple truths they grasp quickly enough, but too readily erect them uncemented into a system.

$I$ have not been able to speak of the German authoress of the nineteenth century with full-blown eulogy. However, the reader has not failed to observe in her story the marks of an up-grade movement calculated to disarm the pessimist. It is certainly a fact from which women ambitious for their sex may derive much gratification, that one cannot name the foremost living writers of Germany without including several women.

And as for the vexed problem that springs into view every time the woman question comes up in literary criticism: Is woman excluded by natural limitations from the higher realms of creative art? I might answer: Ricarda Huch 1 . . . to be told, probably, that one swallow does not make a summer. So again, as at the outset, I ask permission to leave the question open. It was not the object of this sketch to prove a thesis, but rather to trace a development, and to describe the resultant situation. 



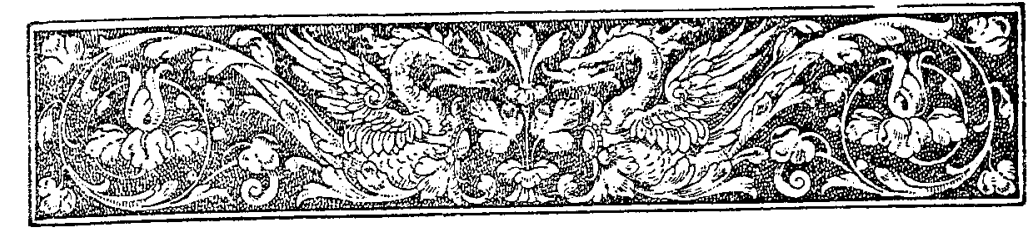

Nachdruck verboten. - Alle Rechte vorbehalten.

\section{Vorwort.}

Der im Sommer 1896 im Berliner Rathause abgehaltene Internationale Frauen-Kongress, dessen ausdauernde und aufmerksame Zuhörerin die Herausgeberin war, erregte ihr lebhaftestes Interesse für die auf diesem Kongresse behandelten Fragen, die man im Allgemeinen als "Frauenfrage" bezeichnet, und der sie bisher fern stand, da sie durch Haus- und Familienpllichten sowie die thätige Mithilfe an den Berufsarbeiten ihres Gatten vollauf in Ansmruch genommen war. Bis dahin war ihr die geistige Thätigkeit der Fran, wenn auch nicht unbekannt, so doch ein von ihr wenig beachtetes und gewïrdigtes Gebiet. Erst auf diesem Kongresse wurde sie gewahr, wieviel Intelligenz, Wissen, Energie und zielbewusstes Streben, Eigenschaften, die man nur bei Männern zu finden gewohnt ist, auch bei Frauen vorhanden sind. Auf sie machten diese Wahrnohmungen einen um so tieferen Eindruck, als sie sich auch zu jenen Frauen zählen darf, die ihre stellung in der Gesellschaft zumeist der eigenen Eraft und dem ernsten Streben za danken haben.

Das oben angedeutete Interesse veranlasste sie in der Frauenlitteratur Unschau zu halten. Dabei machte sie die Wahrnehmung, litteratur riesiges Anwachsen des von der Frau und über die Fran dass ein rien innerhalb der letzten 30 Jahre zu verzeichnea ist, dass aber ein übersichtliches, das ganze Gebiet umfassendes Nachschlagewerk, welches über die Frauenthätigkeit anf litterarischem Gebiete ein einwandfreier und zuverlässiger Wegweiser sein könnte, nirgends un finden ist. Die verschiedenen, die gesamten Schriftsteller umfassenden Lexika, in welchen auch weibliche Autoren sich faden, sind 
schon deshalb nicht zuverlässig und erschöpfend, weil eine grosse Anzahl der schreibenden Franen, dem Vorurteil sich beugend, oder Anzahl der schreibenden nicht unter ihrem weiblichen Namen iure Arbeiten der Öffentlichkeit übergeben haben und weil in denselben thergen haben and wil in nur die Bücher schreibende Schriftstellerin berïicksichtigt ist, die zahlreichen Frauen der Feder aber, welche als Mitarbeiterinnen von Zeitschriften aller Art, als Übersetzerinnen, Redaktricen u. s. w. eine mehr oder minder ansehnliche Stellnng im Reiche der Feder einnehmen, gar keine Berücksichtigung gefunden haben. Mit der stetig zunehmenden Zahl der Frauenwerke, und mit dem Wachsen der Achtnno, welche ein grosser Teil derselben selbst in der litterarischen Welt sich zo erringen vermochte, wird hoffentlich auch die Scheu sehwinden, mit dem vollen Namen für das einzustehen, was man geschrieben hat.

Die Mangelhaftigkeit der vorhandenen Behelfe irgend eine schreibende ${ }^{-F r a n ~ a u f z u f i n d e n, ~ o d e r ~ u ̈ b e r ~ d a s ~ b i s h e r ~ G e l e i s t e t e ~ e i n e r ~}$ "solchen Wissenswertes zu erhalten, legten der Herausgeberin die Idee nahe, einen solchen Behelf zu schaffen und das vorliegende Werk ist die zur That gewordene Idee.

Es liegt der Herausgeberin durchaus fern, für die vorliegende Arbeit jene Zuverlässigkeit und Lückenlosigkeit zu beanspruchen, die sie an den vorhandenen Quellen vermisst und beklagt; sie möchte diese Arbeit als einen Versuch gelten lassen, ein Werk zu schaffen, welches die gerügten Mängel in möglichst geringem Masse anfweist und als ersten Schritt zu dem Ziele, welches ihr vorschwebt. Bei diesem ersten Schritte hat sie aber ein ernstes Streben, ein fester, nicht ermüdender, vor keiner Schwierigkeit und keinem Hindernisse zorückschreckender Wille geleitet, um, wenn auch nicht Vollkommenes, so doch ein Werk zu schaffen, das auch höheren Anforderungen in dieser Richtung entsprechen soll.

Die Herausgeberin kann es sich nicht versagen, an dieser Stelle auszusprechen, dass sie in diesem Streben von beteiligter Seite nicht in dem Hasse unterstützt wurde, wie sie es erwartete, und wie es die Sache als solche verdiente. Das Klagelied des mangelnden Interesses nnd geringen Entgegenkommens, welches alle jene MIänner und Frauen, die ähnlichen Aufgaben sich unterworfen hatten, in den versehiedensten die ähnlichen Aufga ben sich, könnte auch sie anstimmen. Hätten die Damen insbesondere aber die Herren Verleger, welche die wiederDamen, insbesondere and Bitten um Einsendung des verlangten Materials unberücksichtigt liessen, eine Vorstellung, welche unendliche Mühe, peinliche Sorgfalt die Herausgabe eines solchen Werkes erfordert, so würden sie (er Herstellung eines seit 70 Jahren*) nicht mehr erwerkes der Frauenlitteratur das erforderliche Interesse entgegengebracht, und damit der Herausgeberin viel Mï̈he, Zeit, und r. a. erspart haben, and das vorliegende Werk wäre lückenloser geworden.

Alle diese Hemmnisse und Widerwärtigkeiten vermochten aber ihre Kräfte nicht zu erlahmen, verminderten ihr Bemühen nicht, das Erreichbare zu erstreben.

So unangenehm, wenig fördernd, ja abschreckend diese eben berührten Wahrnehmungen einerseits waren, so wurden sie reichlich aufgewogen durch die Fülle von angenehmen Anregungen, welche die arausoeberin im Laufe der Arbeit erhielt, in dem überaus grossen Wollwollen und den sympathischen Kundgebungen, welche ihr von einem grossen Teile der schreibenden Frauenwelt und vielen Männern entgegengebracht wurden und welche, zumal einzelne dieser brieflichen nnd persönlichen Sympathiebezengungen von den Besten der Besten herrühren, ihr eine bleibende und angenehme Erinnerung für das Leben sein werden. Aber noch einen anderen, nicht minder bohen, seelischen und geistigen Genuss bot ihr die Arbeit bei dem Dorchlesen eines grossen Teiles der ihr zugekommenen Autobiogra phieen. Die streng nüchterne Form eines lexikalischen Werkes, sowie der beschränkte Raum verbieten es zu ihrem lebhaften Bedauern, die eingesandten Biographieen unverkürzt wiederzugeben. Sie bedaucrt dies anfrichtig im Interesse desjenigen Teils der Franenwelt, welc'ver aus diesen Biographieen eine Fülle von Anregungen erbalten haben würde. So manche Biographie liest sich wie ein Abschnitt eines sozialen Romans mit all seinen Licht- und Schattenseiten. Nicht imner ist es der innere Drang nach schriftstellerischer Bethätigung, wel sher die Frau in die Reihe der "Schreibenden ${ }^{*}$ gestellt hat. Gar oft waren es die igene Not, die Sorge um die darbende Familie, den siechen Gatten, die vaterlosen Kinder oder die der Unterstützung bedürftigen Geschwister, welche der Tochter, der Gattin, der MIutter oder Schwester die Feder in die Hand drückten, um das in ihr schlummernde Talent auszumünzen und so manche unter ihnen hat thränenden Auges ihre

*) Das einzige Werk dieser Art, wurde unter dem Tisel „Die Deutschen Schriftstellerinnen des 19. Jahrhunderts" heransgegeben yon Karl Wilh. Otto Augrast v. Schindel, in den Jahren 1823-1825, von F. A. Brockhaus in Leipzig verlegt. 
"Humoresken" oder "heiteren" Bilder aus dem Leben geschrieben, gleich dem Komiker, der den nagenden Wurm, den Trübsinn im Herzen, in Ausübung seines Berufes und im Dienste der "heitern Kunst" auf der Bühne, seine und seiner Zuhörer Lachmuskeln in Bewegung setzt.

So manche hat eigenes Unglück z. B. Erblindung, Siechtum, welches die Betreffende seit frühester Jugend auf das Krankenlager geworfen hat und sie für das ganze Leben nicht mehr verlassen soll, zur Schriftstellerin, zur Poetin gemacht. Wie viele Tausende wären diesem namenlosen Unglücke, diesen qualvollen, durch zahllose unmenschliche Operationen erhöhten Leiden geistig erlegen; hier haben diese "Starken" des schwachen Geschlechts Trost und Kraft in dem Selbststudium der versehiedensten Gebiete des Wissens gefunden, bis die "Lust zum Fabulieren ${ }^{4}$ erwachte.

In vielen Fällen zeigt sich die Frau als überaus wertvolle Mitarbeiterin des schriftstellernden Gatten und aus der gemeinsamen Thätigkeit des kongenialen Ehepaares entspringt ein Quell von Ehe-, Familien- und Berufsfreuden, wie sie schöner und edler kaum zu denken sind.

Dieses sich Vertiefen in den Werdeprozess vieler unserer „schreibenden" Frauen würde alle jene, die verächtlich oder mitleidig

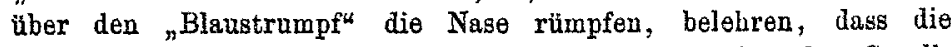
schreibende "Frau den ihr von den. Verhältnissen oder der Gesellschaft aufgebürdeten Daseinskampf ebenso "mannhaft" auszufechten weiss, wie ibr männlicher Kollege. Es würde sie ferner belehren, dass, so kurz anch die Zeit ist, seitdem sie mit der Feder diesen Daseinsbampf zu führen gelernt hat, oder auch ohne diesen Kampf, nur dem inneren Drange folgeud, ihr Wissen and ihr Talent mit der Feder zum Ausdruck bringt, doch schon eine Stellung im Reiche des Geistes sich zu erringen wusste, die von der gebildeten Welt nicht mehr missachtet oder übersehen werden kann.

Anch das könnten Viele, die es nicht schon wissen, aus den Biographieen erfahren, dass die schreibende Frau, ganz entgegen der Annahme des vorurteilsvollen Teiles unserer Gesellschaft, dort, wo sie es sein kann, eine überaus aufopfernde, pflichttreue, hingebungsvolle Hausfrau, Gattin und Mutter ist.

Dass fast jedes Gebiet, auch das der exakten Wissenschaften, von der schreibenden Frau betreten worden ist, wird ein Durchblättern dieses Werkes ebenso bezengen, wie die Thatsache, dass alle Gebiete der Prosa und Poesie ihr heimiseh sind. Es ist aber gar nicht lange her, dass dem nicht so war. Kaum 60 Jahre sind es, da hat, mit geringen Aus- nahmen, der schriftstellerische Drang der Frau in der Abfassung von Koch-, Haushaltungs- und Handarbeitsbïchern seinen sichtbaren Ausdruck und seine Befriedigung gefunden.*)

Von da $a b$ ist ein Vorwärtsschreiten auf litterarischem Falde wahrnehmbar. Schritt für Schritt, anfänglich zaghaft, unsicher, witer einem müunlichen Schild sich verbergend, wird dieses Gebiet von ihr betreten, doch wird sie bald gewahr, dass dasselbe ibr einell guten, fruchtbaren Boden bietet, in welchem die Samenkönner ihres Wissens und ihres Talentes zur üppigen Saat emporkeimen können.

In den 70er Jabren wird das litterarische Feld von der Fran schon sehr reich bestellt und die Früchte ihrer Thätigkeit nehmen auf dem litterarischen IIarkte einen breiten Raum ein. Von da ab wächst der Anteil der Frau an der litterarischen Produktion sehr erbeblich, um in den 90er Jahren, insbesonders 1895-97, einen Stand einzunehmen, der, unter Berücksichtigung aller Verhältnisse zwisehen Mann und Frau, wohl der schreibenden Frau ein sehr günstiges Zengnis ausstellt und sie zu grossen Hoffnangen für ihre soziale Stellung in der Zulkunft berechtigt.

Das Verzeichnis des von Frauen Geschriebenen beginnt in ditsem Werke wit dem Jahre 18:0, (mit Ausnahme des Verzeichnisses der Pseudonyine, welches weit über 200 Jahre zurückreicht, -) wei: dio Auslese weiter zurück eine noch za dürftige ist. Als Quellen für das hier aufgespeicherte Material dienten die Sammelwerke, welche an anderer Stelle namentlich und gewissenhaft genaunt sind. Doch diese

*) Das selr sorgfältig und mühsam zusammengestellte Werk von Elise Oelsner "Die Leistungen der deutschen Frau anf wissenschaftlichem Gebiete" (Verlag von Max Lemke in Guhrau 1894) zählt 3 weibliche Namen aus dem 16. Jahrhunderte, 7 aus dem 17. Jahrhunderte, 40 aus dem 18. Jahrhundert. Auf das erste Drittel des 19. Jahrhunderts fallen etwa 48 weibliche Namen, anf das zweite Drittel 60 , welche schriftstellernd auf den verschiedensten Gebieten der Litteratur thätig waren. Unterstützt werden diese Zahlen durch eine Statistik aus dem ausgezeichneten Werke „Deutsche Dichterinnen and Schriftstellerinnen in Wort und Bild " herausgegeben von Heiurich Gross, 3 Bände, Verlag von Fr. Thiel, Berlin. Es scheint jedoch, dass obgenannte Werke nicht alle schreibenden Frauen dieser Zeit verzeichnen, denn Schindel behauptet in seinem Vorwort, dass das erste Viertel des 19. Jahrhunderts weit über 550 aufweist, allerdings verzeichnet Schindel auch jene Frauen, die irgend ein ungedruckt gebliebenes Gelegenheitsgedicht verfasst haben. 
Quellen gaben nur die Grundlagen, auf denen die Herausgeberin sorgsam und voll Mühe Stein auf Stein das Gebäude aufbaute, in welehem die "schreibende" Frauenwelt heimatberechtigt ist.

Wo sie in den zahllosen Zeitschriften and Prospekten jeglicher Art einen Namen aufstöberte, dessen Trägerin die Feder führt, wo ihr ein solcher Name zugetragen wurde, da flog auch diesem eine gedruckte oder geschriebene Aufforderung za, was sehr oft wiederbolt werden musste, um alle gewïnschten Einzelheiten zu erhalten. Es war, allen sei es geklagt, eine riesige Gednldarbeit und wenn trotzdem Manche und Manches fehlen sollte, so mögen die Kritiker bedeuken, anch das exnsteste Wollen hat seine Grenzen. Anfänglich glaubte die Herausgeberin, in diesem Werke jeder Poetin ein kleines von derselben verfasstes Gedichtchen, gewissermassen als Charakteristikum, mit auf den Weg geben zu können; doch die zu diesem $Z$ wecke erbetenen Poesieen waren so verschiedenartig in Gehalt, Form nnd Ansdelnnung, dass sie sich gezwungen sah, um keiner wehe zu thun, auf den Abdruck der Poesieen zu verzichten. Vielleicht fiplet sich später Zeit and Gelegenheit, die Perlen dieser Poesieen in einem Bande zusammenzufassen und sie der verdienten Würdigung zuzuführen. Eine grosse Zahl der schreibenden Damen verweigerten die erbetenen Mitteilungen, weil sie von der Voraussetzung ausgingen, sie gehörten nicht in das "Lexikon deutscher Schriftstellerinnen", da sie wohl viel für Zeitschriften a. dgl. geschrieben, aber noch kein "Buch" heransgegeben haben. Diese, leider vielseitig geteilte Auffassung, welche den ganzen Zweek und Charakter des Werkes geradezu in Frage stellte, veranlasste die Herausgeberin, den ursprünglichen Titel des Buches: "Lexikon deutscher Schriftstellerinnen" in "Lexikon deutscher Franen der Feder" umzuändern, denn nicht nur die Bücher schreibestio Fran, sondern die schreibende Frau überhaupt, gleichviel in welcher Form sie ihre geistige Thätigkeit mit der Feder zum Ausdruck bringt, soll in diesem Werke zo finden sein und jede schreibende Fran hat die moralische Verpflichtung, sich in Reih und Glied zu stellen, wenn es gilt, Heerschau za halten über die geistige Potenz des weiblichen Geschlechts, die weit unter das Niveau des männlichen zu stellen bisher zu den unantastbaren Lehr- und Erfahrungssätzen unserer Gesellschaft im allgemeinen und vieler Gelehrten und Ärzte im besonderen gehörte.

Diejenigen, welche das Anwachsen der Frauenlitteratur missgünstig verfolgen, werden bei der stattlichen Anzahl von im Dienste der schreibenden Huse stehenden Franen gewiss jammerud ausrufen:
Viel zu viel. Mag sein, aber dasselbe kann von der Zahl der schreibenden Männer gelten und trotzdem, hier wie dort, bahnt sich das wirkliche Talent seinen Weg hoch hinweg über das Eeer mühselig vorwärts sclreitender Talentlosigkeit und anch darin werden die vorliegenden Biographieen Thatsachen erzählen, wie leicht und sohnell es maucher gelungen war, sich Anerkenung zu verschaffen, indes Berge von Manuskripten in den Redaktions- and Verlagsschubladen der Befreiung aus der Gefangenschaft harren.

Überraschende Enthüllungen wird dieses Werk vielen Buchrecensenten bringen, die das Werk eines männlichen Autors zu recensieren glaubten, während es von einer Frau geschrieben wurde.

Besonders mangelhaft sind die Aufzeichnungen der Werke, welche im österreichischen und schweizerischen Buchhandel erschienen sind, weil hier ein besonderes Quellenmaterial überhaupt fehit und das Entgegenkommen seitens der Buchhändler und massgebenden Faktoren dieser beiden Länder noch weit geringer war, als in $D \in$ utschland. Umsomehr fühlt sich die Herausgeberin verpflichtet, aller jenen ganz besonderen Dank an dieser Stelle auszusprechen, welche sie in der wohlwollendsten Weise unterstützt haben. Vorzugsweise gilt dieser Dank der Presse, welche durch bereitwillige Aufnahme, der auf die Heransgabe dieses Werkes bezughabenden Mitteilungen die Sache sehr geförulert hat. Dank gebührt auch Folgenden:

Der Fran Mathilde Clasen-Schmidt, Vorsitzenden des Leipziger Schriftstellerinnenvereins.

Der Fran Dr. Marie Huber (Marie Doebeli) in Grindelwald, Schweiz. Der Frau Lina Morgenstern, Berlin.

Dem Verein der Wiener Schriftstellerimnen nnd Künstlerinnen in Wien. Dem Deutschen Schriftstellerimenbunde in Berlin und vielen Mitgliedern desselben.

Der Frau Johanna Garbald-Gredig (Avdrea Silvia) in Castasegıa bei Graubünden, Schweiz.

Der Hrau liegierungsrat Hermine Tomić in Agram; ferner den Herren: Max Evers, Redakteur des Börsenblattes für den Deutschen Buchlandel. Dr. Wilh. Wendlandt, Leiter des Litterarischen Bureaus des deusschen Schriftsteller-Verbandes, in Berlin.

Dr. H. Stümcke, Herausgeber der Westöstlichen Rundschau in Berlin u. Anderen.

Einen besonderen Teil dieses Nachschlagewerkes bildet das Verzeichniss der "Pseudonyme“, welches in der vorliegenden Ausdehnung vileichfalls das Ergebnis einer überaus sorgfültigen und mühsamen Arbeit 
ist. In keinem anderen bisher bekannten Quellenmaterial findet sich eine so grosse Auzahl deutscher weiblicher Autoren-Pseudonyme vor*) und die Herausgeberin glanbt, einen ganz besonderen Dienst allen jenen damit geleistet $z u$ haben, welche ein Interesse haben, den Namen und die Adresse einer bestimmten, unter einer Maske sich verbergenden Autorin festzustellen.

Erst im Lanfe der Arbeit hat die Herausgeberin den Entschluss gefasst, den Namen der verstorbenen Schriftstellerinnen, die Geburtsund Sterbezeit hinzuzufigen. Doch konnte dieser Entschluss erst nach dem Buchstaben $C$ ausgeführt werden, und auch da nur unvollkommen. Das Fehlende soll bei späteren Auftagen nachgeholt werden.

Alle biographischen Mitteilungen sind von den Autorinnen geprüft, daher zuverlässig.

Mit bangen Gefühlen setzt die Herausgeberin dieses ihr Erstlingswerk in die Welt. Wird es den Beifall der interessierten Kreise finden und der Herausgeberin den Mat verleiten können, das mit vielen Opfern geschaffene Werk zu einer dauernden, in periodischen Zeiträumen neu auflebenden Schöpfung zu gestalten? Wird es ihren höchsten Wunsch, zur Würdigung der Frauenthätiglseit auf litterarisehem Gebiete etwas beigetragen zu haben, verwirklicheu? Die freundliche, ja zum Teil begeisterte Aufnahme, welche ibre Idee bei so Vielen gefunden, lässt sie hoffen, dass auch die bisher woch Gleichgiltigen ihr fernerhin die nötige Unterstützung nicht versagen und mithelfen werden, das Werk zu dem za gestalten, was ihr als Ideal vorschwebt.

Berlin, Januar 1898.

\section{Die Herausgeberin.}

*) Das letzte, von Emil Weller herausgegebene nLexicon Pseudonymorum", das neben den männlichen auch die weiblichen Pseudonyme enthält, ist im Jahre 1886 erschienen.

\section{Verzeichnis der benutzten Quellenschriften.*)}

Allgemeiner deutscher Litteraturkalender Jahrg. 1879-1895, Jahrg. 1-4. Herausgegeben von Heinrich Hart und Julius Hart, Bremen 1879-1880. J. Kühtmanns Verlag, Bremen 1881 Hinricus Fischer, Jahrg. 5-19. Herausgegeben von Prof. Jos. Kürschner Berlin und Stuttgart 188:-89 W. Spemann; Stuttgart u. Eisenach 1890--93 Selbstverlag; Stuttgart 1894-1897 G. J. Goeschen'sche Verlagshandlung.

Franz Bornmüller: Biographisches Schriftstellerlexikon der Gegenwart. Leipzig, 1882. Verlag des Bibliographischen Instituts.

Börsenblatt für den dentschen Buchhandel und die verwandten Gesehüftszweige. Ligentum des Börsenvereius der deutschen Buchhändler zu Leipzig.

Brockhaus Konversationslexikon 16. Bde. Leipzig, F. A. Brockhaus. Franz Brümmer. Lexikon der deutschen Dichter und Prosaisten des neunzehnten Jahrhunderts. 2 Bde. 4. Aufl. Leipzig $1895 \mathrm{Ph}$. Raclam jr.

Robert Clanssner. Ensere Dichter in Wort und Bild. I-III. Band 1891, 1893, 1894. Leipzig, Verlag von Robert Claussner.

Gustar Dakms. Das litterarische Berlin. Berlin, J. Richard Taendler. Das litterarische Leipzig. Illustriertes Handbuch der Schriftstellerund Gelehrtenwelt, der Presse u. des Verlagsbuchhandels in Leipzig. Leipzig, 1897 Walther Fiedler.

Dresdner Frauen-Zeitung. Verlag der Dresdner Franen-Zeitung. Ladw. Eisenberg. Das geistige Wien. Künstler- und Schriftstellerlexikon. Erster Band, Belletristisch künstlicher Teil. Wien 1893. c. Daberkows Verlag.

Heinr. Gross. Deutsche Dichterinnen und Schriftstellerinnen in Wort und Bild. 3 Bände. Berlin, 1885 Fr. Thiel.

*) Die hier angeführten Werke gelten auch als Quellen für den Anlang „Psendonyme“. 
Heinrich Gross: Deutsehlands Dichterinnen und Schriftstellerinnen. Eine litterarhistorische Skizze 2. Ausgabe. Wien, 1882 Carl Gerolds Sohn.

Viktor Hardung. Schweizerischer Litteraturkalender a. d. Jahr 1893. Zürich, Otto Erb's Verlag.

J. C. Hinrichs. Verzeichnis der im deutschen Buchhandel neu erschienenen und neu aufgelegten Bücher, Laudkarten, Zeitsebriften etc. (Halbj. Verzeichnis.) 1840-1897. Leipzig, J. C. Hinrichs'sche Buchhaudlung.

J. C. Hiurichs. Fünfjahrs-Katalog der im deutschen Buchlandel erschienenen Bücher, Zeitschriften, Landkarten. Bd. 1-7. 1851 bis 1895. Leipzig, J. C. Hinrichs'sche Buchhandlung.

Adolf Hinrichsen: Das litterarische Deutschland, Berlin 1891. Verlag des "Litterarisehen Deutschland".

Ednard Fedor Kastner. Böhmens deutsche Poesie und Kunst. Verlag des Herausgebers, Wien.

Heinrich Keiter. Katholischer Litteraturkalender. Regensburg u. Leipzig, 1897. Heinr. Keiter.

Herman Kletke. Doutschlands Jiohterimen, Borlin o. J. (1854) Hermann Hollstein.

Heinr. Kurz. Geschichte der deutschen Litteratur mit ausgewählten Stücken aus den Werken der vorzüglichsten Schriftsteller. Leipzig, 1880/8i. B. G. Tenbner.

Karl L. Leimbach. Die deutschen Dichter der Neuzeit und Gegenwart. 6 Bde. 1883-1896. Frankfurt a/Mr. Kesselring'sche Hofbuchhandlung.

Martin Maacks Dichterlexikon. Die Novelle. Ein kritisches Lexikon über die bekanntesten deutschen Dichter der Gegenwart mit besonderer Berücksichtigung der Novellisten. Lübeck 1896, Verlag der Novellen-Bibliothek.

Jeannot Martinelli. Ein Dichteralbum. Berlin. Verlag o. J. Martinelli.

Meyers Konversationslexikon. 5. Aufl. 17 Bde. Leipzig, Bibliographisches Institut 1894-1898.

Lina Morgenstern. Die Franen des 19. Jahrhunderts. Biographische and kulturhistorische Zeit- und Charakter-Gemälde. 3 Bde. Berlin 1888-1891. Verlag der deutschen Hausfrauen-Zeitung.

Lina Morgenstern. Die 2 letzten Jahrgänge der deutschen Hausfrauen-Zeitung.

Marianne Nigg. Biographieen der österreichischen Dichterinnen und
Schriftstellerinnen. Ein Beitrag zur dentschen Litteratur in Österreich. Korneuburg 1893. Jul. Kühlkopfs Buchhandlung.

Elise Oelsner. Die Leistungen der deutschen Fran in den letzten 400 Jahren auf wissenschaitlichem Gebiete. Guhrau, 1894. Max Lemke.

Karl Wilh. Otto August v. Schindel. Die deutschen Schriftstellerinsen des neunzelnten Jahrhunderts. 3 Bände. 1823-1825. Leipsig, F. A. Brockhans.

Karl Schrattenthal. Die deutsche Franenlyrik unserer Tage. Leipzig o. J., (1892) Leipzig, Karl Naumburg.

Karl Schrattenthal (Karl Weiss). Unsere Franen in einer Auswahl aus ilren Dichtungeu. Stuttgart, 1888. Greiner \& Pfeiffer.

Karl Sehrattenthal (Karl Weiss). Deutsehe Dichterinnen und Schriftstellerinnen in Böhmen, Mähren und Sehlesien. Brünn, 1885 Frd. Irrgang.

Dr. F. Tetzner. Unsere Dichter in Wort and Bild IV. V. VI. Bd. 1894, 1895, 1896. Leipzig, Verlag von Robert Claussner.

Hermann Thom. Deutsche Dichter in Wort und Bild. Poetischer Mausschatz. Leinzig, 1897, Herm. Reinh. Thom's VerlaggAnstult.

Anuy Wothe. Bilde den Geist. Leipzig o. J. (1896.) Adolf Mahns Verlag.

Emil Weller. Lexikon Pseudonymorum. Wörterbuch der Pseudonymen aller Zeiten und Völker. I. u. II. Aufl. 1856, 1886. Regensbarg, Alfred Coppenrath.

Wiener Mode. (Diverse Jahrgänge). Wien, Verlag der Wiener Mode.

Richard Wrede u. Hains von Reinfels. Das geistige Berlin. Kine Encyklopädie des geistigen Lebens Berlins. I. Band. Berlin, 1897. Hugo storm. 